$\mathbb{T}$ periodica polytechnica

\author{
Social and Management Sciences \\ $14 / 2$ (2006) 79-86 \\ doi: 10.3311/pp.so.2006-2.04 \\ web: http://www.pp.bme.hu/so \\ (c) Periodica Polytechnica 2006
}

RESEARCH ARTICLE

\section{Analysis of the Hungarian research and development potential}

\author{
László Molnár
}

Received 2007-09-14

\begin{abstract}
In our days research and development ( $R \mathcal{E} D)$ increases in importance in all sectors of the economy. Recognizing the decisive role in boosting economic competitiveness and productivity of $R \mathcal{E} D$, in March 2002 the European Council decided on increasing RED expenditure to $3 \%$ of GDP in order to bridge the gap between the EU and its major competitors like the United States and Japan. By passing a law on RED and innovation, and introducing a compulsory innovation contribution for companies, Hungary has taken important steps towards this objective. Yet, having reached halftime, the proposed goal seems extremely remote. In this study I will investigate the composition and evolution from the regime change to our days of the Hungarian RED potential, including the number of research units, research intensity and RED expenditure as a percentage of GDP. By means of time-series analysis models I will reveal the Hungarian RED trends of the past 15 years and also predict the feasibility of achieving the EU objective. Towards the end of my study I will investigate the evolution and composition of "down-to-earth" results of the Hungarian RED activity and suggest index numbers for comparison and to measure the results.
\end{abstract}

\section{Keywords}

research and development $\cdot R \mathcal{E} D$ expenditure $\cdot R \mathcal{E} D$ activity indices

\section{László Molnár}

Insitute of Marketing, University of Miskolc, H-3515 Miskolc-Egyetemváros, Hungary

e-mail:marml@uni-miskolc.hu

\section{Introduction}

At present research and development $(\mathrm{R} \& \mathrm{D})$ increases in importance in all sectors of the economy. The government, enterprises and public opinion take a growing interest in this topic. Recognizing the decisive role in boosting economic competitiveness and productivity of R\&D, in March 2002 the European Council decided to increase R\&D expenditure to $3 \%$ of GDP in order to bridge the gap between the EU and its major competitors like the United States and Japan. By passing a law on research and development and innovation, and introducing a compulsory innovation contribution for companies, Hungary has taken important steps towards this objective. Yet, having reached half way, the proposed goal seems extremely remote.

In this study I will investigate the composition and evolution from the regime change to our days of the Hungarian research and development potential, including the number of research units, research intensity and $R \& D$ expenditure as a percentage of GDP. By means of time-series analysis models I will reveal the Hungarian R\&D trends of the past 15 years and also predict the feasibility of achieving the EU objective. At the same time I will use advanced statistical methods to analyse the correlation between the components of the R\&D potential and the index numbers of the national economy. Towards the end of my study I will investigate the evolution and composition of "down-toearth" results of the Hungarian research and development activity, and suggest index numbers for comparison and to measure the results.

\section{Evolution of the Hungarian research and develop- ment potential from the regime change to our days}

Before the analysis of the Hungarian research and development trends, I find it necessary to define exactly what the keyword of my study, research and development means. Research and development is the term for all creative activities which aim to increase the stock of knowledge, including knowledge of nature, humanity, culture and society and the use of this stock of knowledge to devise new applications (Hungarian Central Statistical Office (KSH), 2004, p. 9.).

I will deal with the main components of research and devel- 
opment potential: the number of research units, staff number in R\&D units and R\&D expenditure. These factors illustrate accurately the research and development efficiency of a national economy. Furthermore, statistical yearbooks provide objective and numerical data about them.

Research and development does not end in itself. The new stock of knowledge manifests itself in scientific publications and patents. In the last quarter of this chapter I will treat in detail the alternatives of the measurement of these results.

\subsection{Number of research and development units}

One of the important indicators characterizing the research \& development potential and performance of national economies is the total number of those institutes, enterprises and other places which do basic and applied research and applied development in an effective way. The diagram in Fig. 1 describes the trend of total number of R\&D units from 1990 to 2005 in Hungary.

In the first half decade (1990-1996) after the change of the political regime in Hungary the number of R\&D units was in secular stagnation. There were some 1 250-1 500 R\&D units during this period. The second half of the 1990s saw a powerful growth of R\&D activities, which resulted in some $60 \%$ increase in the number of R\&D units during the next 5 years (1996-2001). But this quick growth came to a sudden halt in 2000, and during the next 3 years (2001-2004) the growth of activities did not reach $10 \%$. Between 2004 and 2005 the number of R\&D units did not only fail to increase, but started to decrease slowly by $1 \%$.

In order to make a precise prediction of the number of R\&D units I used the analytic trend calculation method from mathstatistical time series analysis ${ }^{1}$. Among the tested trend functions a logistic one has proved far the best, due to its strong “explanatory power" $\left(\tilde{s}_{e}^{2}=2\right.$ 859.69)

Based on the analytical trend function the number of R\&D units converges to 2630 , namely, according to my estimation this number was 2593 in 2006, it is 2608 in 2007 and it will be 2617 in 2008 . The application of linear $\left(\tilde{s}_{e}^{2}=15409.10\right)$ and cubic models ( $\tilde{s}_{e}^{2}=5337.28$ ) for calculations results in a good approximation, however in my opinion the former model underestimates and the latter overestimates the increase in the number of R\&D units.

An additional conclusion was drawn, in connection with the units strongly involved in the extension of knowledge, from my investigation of the composition and evolution of R\&D units of higher education, enterprise and R\&D institutes. These results can be seen in Table 1 .

The largest segment of R\&D units (in 2005 62.2\%) can be found at higher education ${ }^{2}$. The rate of increase of these units

\footnotetext{
1 The analytic trend calculation was carried out with Solver extension pack for Microsoft Office 2003.

2 According to the KSH definition R\&D units of higher education are universities, colleges and their departments, clinics and laboratories.
}

has been balanced since 1990, but their proportion is slowly decreasing. R\&D units of enterprises have been gaining more and more ground (29.8\% in 2005). The evolution in this field appears even more obvious if we take into account that the proportion of R\&D units of enterprises was $13.9 \%$ in 1990, and during the last one and a half decades their number has increased by a factor of 4.3. The number and proportion of R\&D institutes and other research units have been stagnating in the last 15 years.

\subsection{Staff number in research and development units}

Another important index for characterizing the $R \& D$ potential is the calculated staff number in R\&D units ${ }^{3}$. These employees are scientists and engineers, technicians, and R\&D assistants directly promoting research and development with their work, as well as other manual and non-manual workers, providing for working conditions (KSH, 2006. p. 367.).

The number of R\&D persons was dramatically cut in the early 1990s. During this period (1990-1996) their number approximately halved from 36384 to 19776 . Since then there has not been considerable change in the data. The index of research intensity, which is the ratio of $R \& D$ employees to the total number of employees in a national economy, has had a similar character during the last one and a half decades. After a gradual decrease (from $0.75 \%$ to $0.54 \%$ ) in the early 1990 s the research-intensity index has been stagnant. Furthermore, the correlation between the number of R\&D persons and national employment figures has a positive and strong character - which is also indicated by the value of the correlation coefficient ${ }^{4}(r=0.98)$.

Attempting to balance the numbers of R\&D persons I used different trend functions. The linear model - although it has a very poor matching $\left(\tilde{s}_{e}^{2}=15005732.57\right)$ - was able to demonstrate the negative tendency in the evolution of the number of R\&D persons. Using a cubic model $\left(\tilde{s}_{e}^{2}=740\right.$ 311.94) I managed to prove this tendency statistically as well. For further optimization the quintic model $\left(\tilde{s}_{e}^{2}=558\right.$ 845.32) was used because the cubic model seems to underestimate the evolution of the number of R\&D persons.

Based on the observable stagnation of the staff number in R\&D units in the last few years and on the prognosis of the quintic trend function I came to the conclusion that no significant change can be expected in the data in the near future. My estimation is that the probable total calculated staff number in R\&D units will be around 19-22 thousand, with the present tendency of gradual decrease continuing in the next two years. Additionally, I estimate a $0.6 \%$ research-intensity index, assuming that there will be no dramatic change in the national employment figures.

\footnotetext{
3 The actual staff number converted to full-time employees, i.e. staff number weighted by the ratio of time spent with actual research and development to the total number of working hours (KSH, 2006. p. 367.).

4 To characterize the correlation I used Pearson's linear correlation coefficient: $r=\frac{\operatorname{cov}(x, y)}{\sqrt{\operatorname{var}(x) \cdot \operatorname{var}(y)}}$, where $\operatorname{cov}(x, y)=\frac{\sum d_{x} \cdot d_{y}}{n}, \operatorname{var}(x)=\frac{\sum d_{x}^{2}}{n}$, and $\operatorname{var}(y)=\frac{\sum d_{y}^{2}}{n}($ Hunyadi - Vita, 2002. p. 588., 589.)
} 


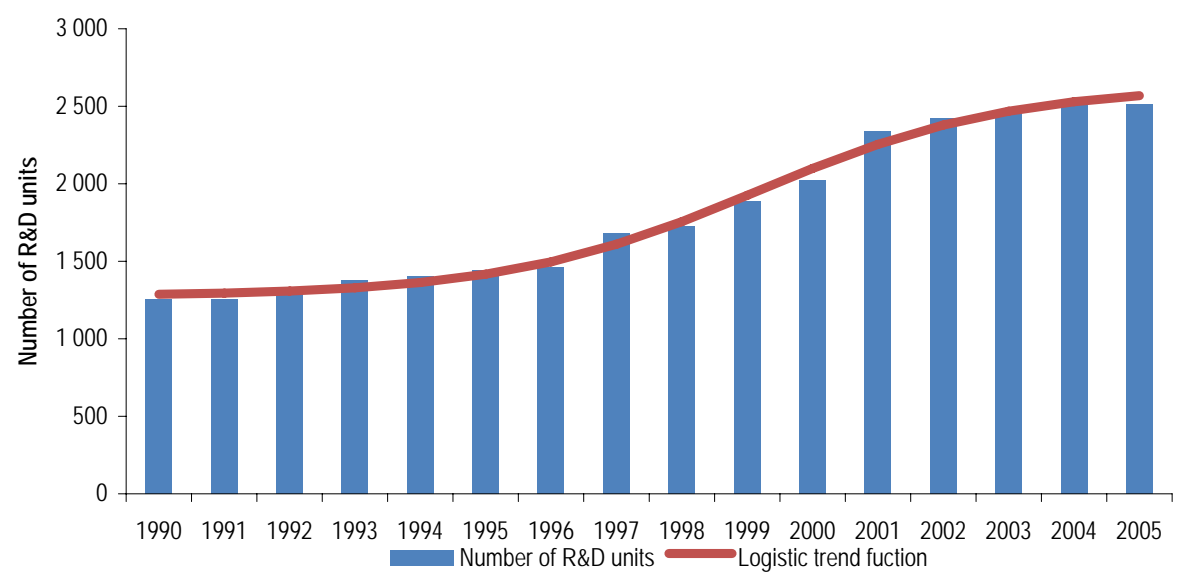

Fig. 1. Total number of research and development units and the logistic trend function. Source: compiled by author from KSH

Tab. 1. Total number of research and development units

\begin{tabular}{llccccccc}
\hline Year & \multicolumn{2}{c}{$\begin{array}{c}\text { R\&D institutes, } \\
\text { other research units }\end{array}$} & \multicolumn{2}{c}{$\begin{array}{c}\text { R\&D units of higher } \\
\text { education }\end{array}$} & \multicolumn{2}{c}{ R\&D units of enterprises } & \multicolumn{2}{c}{ Total number of R\&D } \\
units
\end{tabular}

Source: compiled by author from KSH

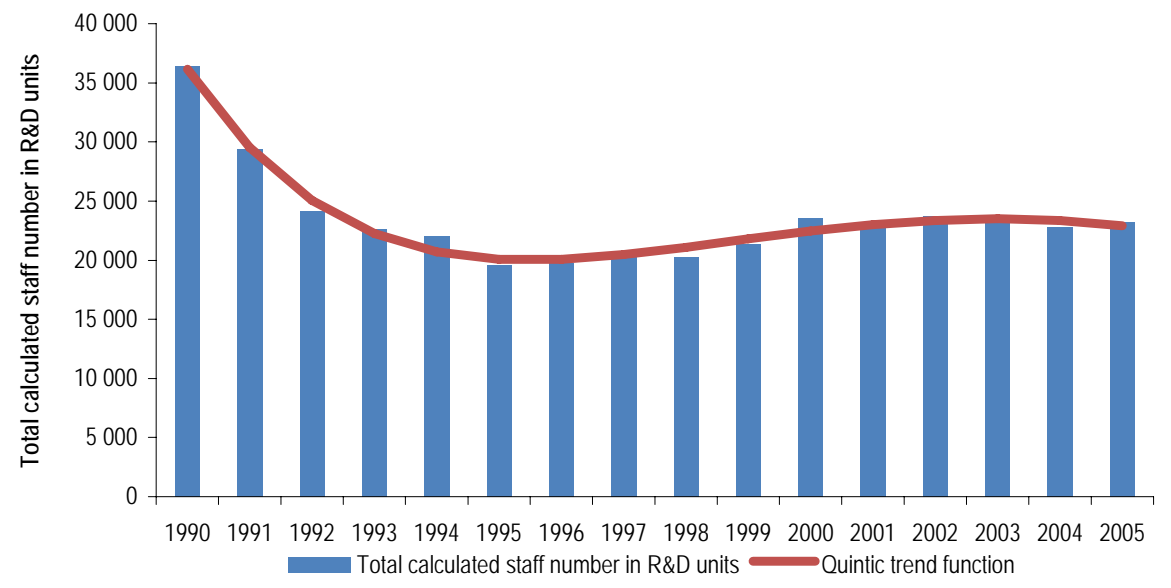

Fig. 2. Total calculated staff number in R\&D units and the quintic trend function. Source: compiled by author from KSH 
Table 2 represents the evolution of the staff number in $R \& D$ units of higher education, enterprises and R\&D institutes between 1990 and 2005. I came to a few further conclusions by investigating the composition of the total calculated staff number.

The distribution of R\&D persons is approximately uniform among the R\&D units of higher education, enterprises and $R \& D$ institutes. The R\&D units of higher education, the R\&D units of enterprises and the R\&D institutes represent $35.3 \%, 31.8 \%$ and $32.9 \%$ respectively of the total staff number. From these figures and from the previously mentioned inner ratios of the R\&D units, one can conclude that the average staff number in R\&D units of higher education is far behind the average staff number of $R \& D$ units of enterprises, which in turn is exceeded by the average staff number of R\&D institutes and other research units exclusively involved in research and development. The estimated value of the concentration index of R\&D units ( $\mathrm{L}=34.3 \%$ ) represents a weak-medium level of concentration in terms of staff number.

\subsection{R\&D expenditure}

One of the most important figures in the statistics of research and development as a creative activity, beside the number of $\mathrm{R} \& \mathrm{D}$ units and the calculated staff number, is the sum of the current and capital expenditures from domestic and foreign sources. The European Union, including Hungary, has decided to increase R\&D expenditure to 3\% of GDP by 2010 Fig. 3 below shows the evolution of the total R\&D expenditure between 1990 and 2005.

In the early and middle 1990s Hungary's total R\&D expenditure was around 35-45 billion HUF per year, aggregating 0.67$1.08 \%$ of the country's GDP calculated at the current rate. After the turning-point in 1996 - in close relation with the rate of growth of the GDP - R\&D expenditures started to increase unsteadily. The strength and direction of the connection can readily be characterized by Pearson's linear correlation coefficient $(r=0.98)$. However, the rate of growth of the sum of current and capital expenditures could not exceed the rate of growth of the GDP, thus the rate of the R\&D expenditures in GDP remained between 0.74 and $1.00 \%$.

I made the statistical fitting of the time series of the R\&D expenditures increasing year by year with three alternatives. Although the fits of both the linear $\left(\tilde{s}_{e}^{2}=475562\right.$ 932.16) and the exponential $\left(\tilde{s}_{e}^{2}=154344381.52\right)$ functions are acceptable, I used the following cubic model for forecasting. This trendfunction is actually the "golden mean" between the linear and the exponential functions, and that is confirmed by its index of fit $\left(\tilde{s}_{e}^{2}=96423\right.$ 194.84).

According to the prognosis made by the cubic model, the total R\&D expenditure was around 260 billion HUF in 2006, and it will be 300 billion HUF in 2007 and 350 billion HUF in 2008. If the GDP's rate of growth continues, the rate of R\&D expenditure as a percentage of GDP is excepted to stay under $1.00 \%$.
The largest part of the R\&D expenditure is coming from the current expenditure, but investment also costs several billions. Table 3 shows the evolution of the volume of current R\&D expenditures and investments, as well as their percentage in the total expenditures.

After a stagnation in the early 1990s (21-39 billion HUF/year), R\&D current expenditure started to increase steadily in the middle of the decade. In 9 years (1996-2005) the yearly volume of $\mathrm{R} \& \mathrm{D}$ costs increased 4.3 times. However during the whole period the proportion of current expenditure was unchanged, giving 75-85\% of the R\&D expenditure. In the last 16 years capital expenditures have followed nearly the same trend. Stagnation is seen in the early 1990s, then a 6-fold increase from 1996.

Further important questions in the analysis of R\&D expenditure are as follows: how are they divided among the different R\&D units, and what are their sources and what are they used for?

In 2005 , nearly $45 \%$ of the total $R \& D$ expenditure was used by $R \& D$ units of enterprise, with the number of these units being only one third of the all R\&D units and complement. The research institutes expended $29 \%$, while the higher education sector - with the most R\&D units and largest complement expended hardly more than a quarter of the expenditure. The R\&D units of the tertiary education segment have the smallest budget for research and development, an average of 33 million $\mathrm{HUF} / \mathrm{year}$, while the research institutes and the R\&D units of enterprises have a budget of 290 million HUF and 120 million HUF per year respectively.

Regarding the financial sources, near half of the expenditure is coming from state budget. A further $40 \%$ is coming from the enterprises' own budget or from other enterprises that they have a contract with, or from support. The sum from international organizations through order, support, aid or tender give $10 \%$ of the expenditure. (There is also some national support, but its percentage is less than $0.5 \%$.)

In 2005 nearly $60 \%$ of total R\&D expenditure was expended on research. Within this, the resources were used nearly in the same proportion for basic and applied research. For experimental development $40 \%$ of the expenditure were used.

\subsection{Results of research and development and the methods of its measurement}

The Hungarian statistical practice uses the quantitative data of scientific publications and patents to measure the results of the research and development units. Scientific publications are books, chapters, articles in Hungarian or foreign scientific journals and accepted theses in Hungarian or foreign language written by employees of research institutes. Patents are all industrially applicable inventions based on new invent activity (KSH, 2004, p. 21-22.).

The number of scientific publications has not changed for five years (2000-2005), staying around 36-40 thousand each year. 
Tab. 2. Total calculated staff number in $R \& D$ units

\begin{tabular}{|c|c|c|c|c|c|c|c|c|c|}
\hline \multirow{2}{*}{$\begin{array}{l}\text { Year } \\
1990\end{array}$} & \multicolumn{2}{|c|}{$\begin{array}{c}\text { R\&D institutes, } \\
\text { other research units }\end{array}$} & \multicolumn{2}{|c|}{$\begin{array}{c}\text { R\&D units of higher } \\
\text { education }\end{array}$} & \multicolumn{2}{|c|}{ R\&D units of enterprises } & \multicolumn{2}{|c|}{$\begin{array}{l}\text { Total calculated staff } \\
\text { number in R\&D units }\end{array}$} & \multirow{2}{*}{$\begin{array}{c}\begin{array}{r}\text { Research } \\
\text { intensity }\end{array} \\
0.75 \%\end{array}$} \\
\hline & 14524 & $39.9 \%$ & 8843 & $24.3 \%$ & 13017 & $35.8 \%$ & 36384 & $100.0 \%$ & \\
\hline 1991 & 11909 & $40.5 \%$ & 8458 & $28.8 \%$ & 9030 & $30.7 \%$ & 29397 & $100.0 \%$ & $0.65 \%$ \\
\hline 1992 & 10235 & $42.3 \%$ & 7917 & $32.7 \%$ & 6040 & $25.0 \%$ & 24192 & $100.0 \%$ & $0.59 \%$ \\
\hline 1993 & 9164 & $40.5 \%$ & 7776 & $34.4 \%$ & 5669 & $25.1 \%$ & 22609 & $100.0 \%$ & $0.59 \%$ \\
\hline 1994 & 8343 & $37.9 \%$ & 7611 & $34.6 \%$ & 6054 & $27.5 \%$ & 22008 & $100.0 \%$ & $0.59 \%$ \\
\hline 1995 & 7739 & $39.5 \%$ & 6310 & $32.2 \%$ & 5536 & $28.3 \%$ & 19585 & $100.0 \%$ & $0.53 \%$ \\
\hline 1996 & 9080 & $45.9 \%$ & 6558 & $33.2 \%$ & 4138 & $20.9 \%$ & 19776 & $100.0 \%$ & $0.54 \%$ \\
\hline 1997 & 8866 & $42.7 \%$ & 7210 & $34.7 \%$ & 4682 & $22.6 \%$ & 20758 & $100.0 \%$ & $0.57 \%$ \\
\hline 1998 & 7815 & $38.5 \%$ & 7561 & $37.2 \%$ & 4939 & $24.3 \%$ & 20315 & $100.0 \%$ & $0.55 \%$ \\
\hline 1999 & 7978 & $37.4 \%$ & 7452 & $34.9 \%$ & 5899 & $27.7 \%$ & 21329 & $100.0 \%$ & $0.56 \%$ \\
\hline 2000 & 8204 & $34.9 \%$ & 8859 & $37.6 \%$ & 6471 & $27.5 \%$ & 23534 & $100.0 \%$ & $0.61 \%$ \\
\hline 2001 & 7766 & $33.9 \%$ & 8397 & $36.6 \%$ & 6779 & $29.5 \%$ & 22942 & $100.0 \%$ & $0.59 \%$ \\
\hline 2002 & 7979 & $33.7 \%$ & 8528 & $36.0 \%$ & 7196 & $30.4 \%$ & 23703 & $100.0 \%$ & $0.61 \%$ \\
\hline 2003 & 7859 & $33.7 \%$ & 8272 & $35.5 \%$ & 7180 & $30.8 \%$ & 23311 & $100.0 \%$ & $0.59 \%$ \\
\hline 2004 & 7595 & $33.3 \%$ & 8527 & $37.4 \%$ & 6704 & $29.4 \%$ & 22826 & $100.0 \%$ & $0.59 \%$ \\
\hline 2005 & 7652 & $32.9 \%$ & 8194 & $35.3 \%$ & 7393 & $31.8 \%$ & 23239 & $100.0 \%$ & $0.60 \%$ \\
\hline
\end{tabular}

Source: compiled by author from KSH

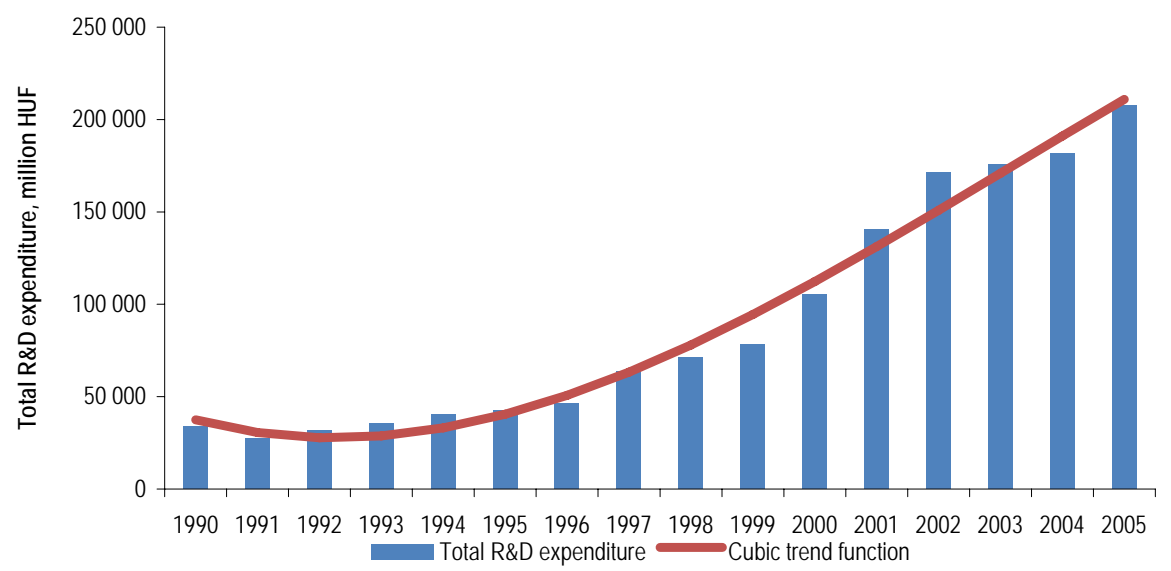

Fig. 3. Total R\&D expenditure and the cubic trend function. Source: compiled by author from KSH 
Tab. 3. Total R\&D expenditure

\begin{tabular}{|c|c|c|c|c|c|c|c|}
\hline \multirow{2}{*}{$\begin{array}{l}\text { Year } \\
1990\end{array}$} & \multicolumn{2}{|c|}{$\begin{array}{c}\text { R\&D current expenditure, } \\
\text { million HUF }\end{array}$} & \multicolumn{2}{|c|}{$\begin{array}{c}\text { Capital expenditure, } \\
\text { million HUF }\end{array}$} & \multicolumn{2}{|c|}{$\begin{array}{c}\text { Total R\&D expenditure, } \\
\text { million HUF }\end{array}$} & \multirow{2}{*}{$\begin{array}{c}\text { R\&D } \\
\begin{array}{c}\text { expenditure as } \\
\text { a percentage } \\
\text { as of GDP }\end{array} \\
1.61 \%\end{array}$} \\
\hline & 21164 & $62.8 \%$ & 3317 & $9.8 \%$ & 33725 & $100.0 \%$ & \\
\hline 1991 & 21191 & $78.2 \%$ & 2209 & $8.2 \%$ & 27103 & $100.0 \%$ & $1.08 \%$ \\
\hline 1992 & 23044 & $72.9 \%$ & 3359 & $10.6 \%$ & 31632 & $100.0 \%$ & $1.07 \%$ \\
\hline 1993 & 25012 & $70.9 \%$ & 3593 & $10.2 \%$ & 35253 & $100.0 \%$ & $0.99 \%$ \\
\hline 1994 & 31311 & $77.7 \%$ & 4680 & $11.6 \%$ & 40289 & $100.0 \%$ & $0.92 \%$ \\
\hline 1995 & 35030 & $82.8 \%$ & 4712 & $11.1 \%$ & 42310 & $100.0 \%$ & $0.75 \%$ \\
\hline 1996 & 39041 & $84.8 \%$ & 5332 & $11.6 \%$ & 46027 & $100.0 \%$ & $0.67 \%$ \\
\hline 1997 & 49044 & $77.1 \%$ & 8141 & $12.8 \%$ & 63591 & $100.0 \%$ & $0.74 \%$ \\
\hline 1998 & 56240 & $79.0 \%$ & 11380 & $16.0 \%$ & 71186 & $100.0 \%$ & $0.71 \%$ \\
\hline 1999 & 61467 & $78.6 \%$ & 12711 & $16.3 \%$ & 78188 & $100.0 \%$ & $0.69 \%$ \\
\hline 2000 & 81356 & $77.2 \%$ & 18152 & $17.2 \%$ & 105388 & $100.0 \%$ & $0.80 \%$ \\
\hline 2001 & 105230 & $74.8 \%$ & 23727 & $16.9 \%$ & 140605 & $100.0 \%$ & $0.92 \%$ \\
\hline 2002 & 134166 & $78.2 \%$ & 26125 & $15.2 \%$ & 171470 & $100.0 \%$ & $1.00 \%$ \\
\hline 2003 & 138523 & $78.8 \%$ & 28106 & $16.0 \%$ & 175773 & $100.0 \%$ & $0.93 \%$ \\
\hline 2004 & 147708 & $81.4 \%$ & 25188 & $13.9 \%$ & 181525 & $100.0 \%$ & $0.88 \%$ \\
\hline 2005 & 167924 & $80.8 \%$ & 32197 & $15.5 \%$ & 207764 & $100.0 \%$ & $0.94 \%$ \\
\hline
\end{tabular}

Source: compiled by author from $\mathrm{KSH}$

12-14 percent of these publications were books in Hungarian or foreign language, the other 86-88 percent being articles in scientific journals. Patents show a different trend, namely the number of patent applications has dramatically decreased in the last years. While between 2000 and 2003 the Hungarian Patent Office (MSZH) filed 5 thousand patent applications a year, this number has reduced to 2.7 thousand in 2004 and only 1.3 thousand in 2005 (MSZH, 2006, p. 31.).

\subsubsection{Technological Activity Index}

There are multi-component index numbers to measure the results of research and development units whereof I will introduce the Technological Activity Index (TAI). This is the first component of the Innovation Capability Index (UNICI) developed by the United Nations Conference on Trade and Development (UNCTAD). This index number includes the following components with equal weights:

- R\&D personnel per million population

- United States patents granted per million population

- Scientific publications per million population (UNCTAD, 2005, p. 113.)

The prime advantage of the Technological Activity Index is that we can draw international comparisons from it. However, interpreting this index number is extremely difficult, because it averages population deflated values of factors measured in different units.

\subsubsection{R\&D activity indices}

To measure the "down-to-earth" results of research and development units I have developed a much easier renderable method.
This statistical method contains two index numbers: a raw and a pure index number.

\subsubsection{Raw index number}

The raw index number of R\&D activity shows the weighted sum of scientific publications and patent applications per population in a given year. The concrete value can be calculated with the following formula.

$$
P P E=\frac{\sum_{i}^{n} W_{P u_{i}} \cdot P u_{i}+\sum_{j}^{m} W_{P a_{j}} \cdot P a_{j}}{E} \cdot 100
$$

E $\quad-\quad$ Employment

$P a_{j} \quad-\quad$ Number of the j-type patents

$P P E \quad-\quad$ Raw index number of R\&D activity (Publications and Patents per Employment)

$P u_{i} \quad-\quad$ Number of the i-type publication

$W_{P a_{j}} \quad-$ Weight of the j-type patent

$W_{P u_{i}} \quad$ - Weight of the i-type publication

In my opinion weighting is necessary because writing an article, a chapter, a book, bringing out a conference publication or filing a patent application indicates different research and development activity.

\subsubsection{Pure index number}

The pure index of $R \& D$ activity divides the weighted sum of scientific publications and patents by the total staff number in R\&D units. Its formula varies from that of the raw index only in 
the denominator.

$$
P P P=\frac{\sum_{i}^{n} W_{P u_{i}} \cdot P u_{i}+\sum_{j}^{m} W_{P a_{j}} \cdot P a_{j}}{P} \cdot 100
$$

$P \quad-\quad$ R\&D personnel

$P a_{j} \quad-\quad$ Number of the j-type patents

$P P P \quad-\quad$ Pure index number of R\&D activity

(Publications and Patents per Personnel)

$P u_{i} \quad-\quad$ Number of the i-type publication

$W_{P a_{j}} \quad$ - Weight of the j-type patent

$W_{P u_{i}}-$ Weight of the i-type publication

It is easy to see that the quotient of my $R \& D$ activity index numbers will give the research intensity, which is the ratio of the number of R\&D personnel among the employed.

(The most important advantage of the R\&D activity indices, in contrast with quantitative data and multicomponent indicators is that they can quantify the "down-to-earth" results of the R\&D activity, differentiate between various publications and patents, they can be calculated simply and quickly and they are easily renderable.)

In my analysis of the Hungarian research and development activity I calculated the concrete values of the raw and pure index numbers between 2000 and 2005. I summarized the results in the following Table 4.

Tab. 4. Raw and pure index number of R\&D activity

\begin{tabular}{lllllll}
\hline Year & Papers & Books & Patents & PPE & PPP & $\begin{array}{l}\text { Research } \\
\text { intensity }\end{array}$ \\
\hline 2000 & 32985 & 4278 & 4883 & $\mathbf{1 . 0 9}$ & $\mathbf{1 7 9 . 0 9}$ & $0.61 \%$ \\
2001 & 34197 & 4393 & 5451 & $\mathbf{1 . 1 4}$ & $\mathbf{1 9 1 . 9 7}$ & $0.59 \%$ \\
2002 & 35422 & 4906 & 5906 & $\mathbf{1 . 1 9}$ & $\mathbf{1 9 5 . 0 6}$ & $0.61 \%$ \\
2003 & 34595 & 4859 & 4810 & $\mathbf{1 . 1 3}$ & $\mathbf{1 8 9 . 8 8}$ & $0.59 \%$ \\
2004 & 31527 & 4972 & 2657 & $\mathbf{1 . 0 0}$ & $\mathbf{1 7 1 . 5 4}$ & $0.59 \%$ \\
2005 & 33412 & 4745 & 1275 & $\mathbf{1 . 0 1}$ & $\mathbf{1 6 9 . 6 8}$ & $0.60 \%$ \\
\hline
\end{tabular}

Source: compiled by author from $\mathrm{KSH}$

The evolution of the Hungarian R\&D activity showed a curvelike tendency at the start of the new millennium. The indices of the activity were increasing gradually from 2000 to 2002 (PPE: from 1.09 to 1.19; PPP: from 179 to 195). After that the R\&D activity decreased below the initial level during the same length of time (PPE: from 1.19 to 1.00; PPP: from 195 to 170). Between 2004 and 2005 there was no change in the Hungarian R\&D activity.

\section{Conclusion and recommendation}

Finally I briefly summarize and conclude the results obtained from my studies in connection with R\&D activities in Hungary.

1 In the first 5 years after the political changes the number of R\&D units stagnated. After that, a period of progressive increase was followed by a regressive period in the past few years. This tendency can be perfectly described by logistic trend functions. According to my prognosis the increasing trend will continue but with a decreasing rate.

2 The number of R\&D persons dropped dramatically in the mid 1990s and it has practically remained unchanged since then. The same is valid for the research intensity index, which shows the ratio of the number of R\&D persons to the total number of employees. In my analysis I proved that there is a close and statistically significant correlation between the number of R\&D persons and the total number of employees.

3 Similarly to R\&D units, R\&D expenditure in Hungary started to grow progressively from the mid 1990s. However, the EU recommendation that $\mathrm{R} \& \mathrm{D}$ expenditure has to reach $3 \%$ of the GDP by 2010 seems impossible to fulfil. The correlation between the expenditures and the GDP is also strong and statistically significant.

4 In Hungarian statistical practice natural units are used for measuring the efficiency of R\&D activities, but international literature also applies complex parameters such as the Technological Activity Index introduced by UNCTAD.

5 On the other hand I recommend the application of the raw R\&D activity index (PPE) for measuring scientific publications, patents and other $R \& D$ results on the level of the national economy. This index enables comparative investigation in time and space.

6 I recommend that the pure R\&D activity index (PPP) should be applied for the characterization of R\&D persons' scientific activity. Both above mentioned indices are easy to calculate and interpret, and they perfectly describe the subjects under investigation.

\section{References}

1 2003. évi XC. törvény a Kutatási és Technológiai Innovációs Alapról: (Act $X C$ of 2003 on the Research and Technological Innovation Fund).

2 2004. évi CXXXIV. törvény a kutatás-fejlesztésról és a technológiai innovációról: (Act CXXXIV of 2004 on RED D and technological innovation).

3 Hunyadi L, Mundruczó Gy, Vita L, Statisztika: (Statistics), Aula, Budapest, 1997.

4 Hunyadi L, Vita L, Statisztika közgazdászoknak: (Statistics for Economists), KSH, 2002.

5 Jánosa A, Adatelemzés számítógéppel: (Data analysis with computer), Perfekt, Budapest, 2006.

6 available at KPI: wWw. kpi.gov.hu.

7 A K+F statisztika módszertana: (Methodology for statistics on REDD), KSH, Budapest, 2004.

8 Kutatás és fejlesztés: (Research and Development), KSH, Budapest, Unknown Month 2004.

9 Magyar Statisztikai Évkönyv: (Hungarian Statistical Yearbook), KSH, Budapest, Unknown Month 2004.

10 available at KSH: www. ksh.hu.

11 NKTH: Jelentés a Kormány részére a Nemzeti Kutatási és Technológiai Hivatal 2005. évi tevékenységéról, valamint a Kutatási és Technológiai Innovációs Alap felhasználásáról (Tervezet): (Report for the Hungarian Government on the work of National Organization for Research and Technology and on untilization of the Research and Technological Innovation Fund 2005), Budapest, 2006. 
12 available at NKTH: www.nkth.gov.hu.

13 Nyitrai F, Gazdaságstatisztika: (Economic Statistics), KSH, Budapest, 1996.

14 MSZH: Éves jelentés 2005: (Annual Report 2005), Budapest, 2006.

15 OM: Kutatás és fejlesztés Magyarországon: (Research and Development in Hungary), Budapest, Unknown Month 2000.

16 Rappai G, Üzleti statisztikai Excellel: (Business Statistics with Excel), KSH, Budapest, 2001.

17 Simon Gy, Gazdasági növekedés és kutatás-fejlesztés: a svéd és finn példa

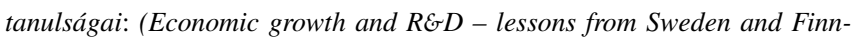
land), Statisztikai Szemle (2006), 1046-1077.

UNCTAD: World investment report 2005: Transnational corporations and internationalization of R\&D, New York - Geneva, United Nations, 2005. 